\title{
Gambaran Perkembangan Bicara dan Bahasa Anak Usia 0-3 Tahun
}

Gladys Gunawan, ${ }^{*}$ Destiana $R,{ }^{*}$ Kusnandi Rusmil ${ }^{* *}$

* Bagian Tumbuh Kembang/Pediatri Sosial-Bagian/SMF Ilmu Kesehatan Anak FK Unlam/RSUD Ulin Banjarmasin

** Departmen Ilmu Kesehatan Anak, Fakultas Kedokteran, Universitas Padjadjaran, Rumah Sakit Hasan Sadikin, Bandung

Latar belakang. Deteksi dini penyimpangan perkembangan anak merupakan tema global utama dalam pelayanan kesehatan anak saat ini. Kegiatan deteksi dimaksudkan untuk menyingkirkan adanya penyimpangan tumbuh kembang anak dan melihat faktor risiko yang mempengaruhinya. Kemampuan bicara dan bahasa merupakan salah satu indikator perkembangan anak yang sangat penting. Perubahan sosial dan demografi telah menyebabkan jumlah anak yang menerima perawatan dari seseorang yang bukan orangtuanya semakin bertambah, dan sebagian menitipkan anaknya di Tempat Penitipan Anak (TPA).

Tujuan. Mengetahui gambaran perkembangan bicara dan bahasa anak usia 0-3 tahun di TPA Banjarmasin.

Metode. Penelitian deskriptif secara cross-sectional, dengan metode purposive sampling. Subjek penelitian adalah 33 anak usia 0-3 tahun yang dititipkan di delapan TPA di Banjarmasin. Instrumen penelitian yang digunakan adalah alat skrining yang dipakai Early Languange Milestone scale-2, kuesioner terhadap orang tua, dan pengasuh anak di TPA.

Hasil. Hasil penelitian dengan ELMs-2 menunjukkan bahwa $100 \%$ subyek dinyatakan pass atau menunjukkan perkembangan bahasa dan bicara yang normal. Kuesioner terhadap orang tua dan pengasuh anak di TPA menunjukkan bahwa tingkat pendidikan orang tua dan pengasuh TPA berada di tingkat tinggi. Subyek penelitian berasal dari keluarga dengan tingkat ekonomi yang baik.

Kesimpulan. Perkembangan bicara dan bahasa anak usia 0-3 tahun di delapan TPA Banjarmasin adalah normal, sesuai dengan tahapan perkembangan pada usia masing-masing anak.

Sari Pediatri 2011;13(1):21-5.

Kata kunci: perkembangan bicara dan bahasa, tempat penitipan anak, early language milestone-2

Alamat korespondensi:

Dr. Gladys Gunawan, Sp.A. Ketua Subdivisi Gizi dan Tumbuh Kembang RSUD Ulin. Jl. Jend. A. Yani No. 43, Banjarmasin Kalimantan Selatan 70233. Telp. +62511-3269177, Fax. +62511-3269177

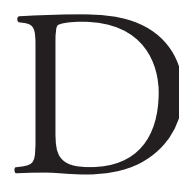
eteksi dini penyimpangan pertumbuhan dan perkembangan anak merupakan tema global utama dalam pelayanan kesehatan anak saat ini. Kegiatan deteksi dimaksudkan untuk menyingkirkan penyimpangan tumbuh kembang anak dan menilai faktor risiko 
yang mempengaruhinya, dengan harapan tindakan intervensi dapat dilakukan sedini mungkin, sehingga proses tumbuh kembang selanjutnya dapat berlangsung secara optimal. ${ }^{1,2,3}$

Gangguan bicara merupakan salah satu masalah yang sering terdapat pada anak-anak. Menurut National Center for Health Statistics (NCHS), berdasarkan laporan orang tua (di luar gangguan pendengaran serta celah pada palatum), angka kejadian gangguan bicara 0,9\% pada anak di bawah usia 5 tahun, dan 1,94\% pada usia 5-14 tahun. Hasil evaluasi langsung terhadap anak usia sekolah menunjukkan angka kejadian 3,8 kali lebih tinggi daripada hasil wawancara. Berdasarkan hasil ini, diperkirakan gangguan bicara dan bahasa pada anak adalah sekitar $4-5 \%{ }^{1}$

Kemampuan berbahasa sensitif terhadap keterlambatan atau kerusakan pada sistem lain, sebab melibatkan kemampuan kognitif, sensori motor, psikologis, emosi, dan lingkungan di sekitar anak. Bicara merupakan salah satu cara untuk mengekspresikan bahasa. Mereka harus belajar mengekspresikan dirinya, membagi pengalamannya dengan orang lain, dan menemukan keinginan. Periode kritis bagi perkembangan bicara dan bahasa anak adalah 9-24 bulan dari awal kehidupan. ${ }^{1,4}$

Perubahan sosial dan demografi yang menyeluruh telah menyebabkan jumlah anak yang menerima perawatan dari seseorang yang bukan orangtuanya semakin bertambah. Wanita bekerja karena alasan yang sama seperti laki-laki, yaitu untuk kebutuhan dan aktualisasi diri. Keadaan ekonomi dan perubahan struktur keluarga memerlukan ketersediaan pelayanan perawatan anak untuk orang tua yang sedang bekerja. Pengaruh perawatan anak pada perkembangan anak tergantung pada beberapa faktor yang saling berhubungan, termasuk sifat-sifat anak, keadaan perawatan, dan keadaan keluarga. ${ }^{5}$ Penelitian National Institute of Child Health and Human Development menemukan bahwa anak berumur di atas 6 bulan yang memiliki pengalaman di pusat perawatan anak menunjukkan perkembangan kognitif dan bahasa yang lebih baik ${ }^{6}$

Perkembangan bicara dan bahasa usia 0-3 tahun yang memperoleh pengasuhan di luar rumah seperti Taman Penitipan Anak (TPA) di Banjarmasin belum pernah diteliti, sehingga belum diketahui bagaimana gambaran perkembangan bicara dan bahasa yang sebenarnya terjadi. Tujuan penelitian ini mengetahui gambaran perkembangan bicara dan bahasa pada anak usia 0-3 tahun di Taman Penitipan Anak di Banjarmasin.

\section{Metode}

Penelitian deskriptif mengenai gambaran perkembangan bicara dan bahasa anak usia 0-3 tahun di TPA Banjarmasin, dilakukan dengan desain cross-sectional. Subjek penelitian adalah anak usia 0-3 tahun yang berada di Taman Penitipan Anak di Banjarmasin, bersedia menjadi responden, dan tanpa ada kelainan kongenital mayor (sindrom Down dan kelainan genetik lain). Teknik pengambilan sampel penelitian dengan purposive sampling. Instrumen yang digunakan pada penelitian adalah lembar uji dan peralatan Early Languange Milestone scale-2. Penelitian dilaksanakan di delapan Tempat Penitipan Anak di Banjarmasin pada bulan April sampai Mei 2010. Anak yang menjadi subjek penelitian dicatat identitasnya. Selanjutnya anak diminta melakukan gugus tugas sesuai umur untuk setiap sektor perkembangan dalam lembar uji $E L M s$-2, dimulai dari sektor yang paling mudah dan dimulai dengan tugas perkembangan yang terletak di sebelah kiri garis umur, kemudian dilanjutkan sampai ke kanan garis umur. Dari pengamatan terhadap anak, diberi penilaian gagal atau dapat mengerjakan gugus tugas dengan benar sesuai dengan pedoman standart. Kemudian, diambil kesimpulan, apakah perkembangan bahasa dan bicara anak tersebut normal atau tidak normal. Pengasuh dan orang tua diminta untuk mengisi kuesioner yang telah disediakan.

\section{Hasil}

Subjek penelitian berasal dari delapan tempat penitipan anak di Banjarmasin, yaitu TPA Uma Kandung, TPA Kasih Sayang Bunda, TPA Halimatus Sadiyah, TPA Anak Mandiri, TPA Ar Rahman, TPA Bunga Bangsa, TPA Citra Bunda, dan TPA Bina Sejahtera. Sampel yang diperoleh 33 anak, yang dititipkan di TPA mulai pukul 08.00-17.00 WITA, berusia berkisar 17-35 bulan. Pada umumnya TPA menerima anak yang berusia di atas 12 bulan.

Persentase hasil skrining ELMs-2 pada semua anak usia 0-3 tahun di TPA Banjarmasin adalah $100 \%$ pass atau normal. Hal tersebut menunjukkan bahwa semua anak yang dititipkan oleh orangtuanya di TPA memiliki perkembangan bicara dan bahasa yang normal. Sejauh ini, anak-anak tersebut memiliki tahapan-tahapan kemampuan ekspresif, reseptif, dan visual yang baik sesuai dengan usia mereka, sehingga dapat menjalankan komunikasi yang baik dengan lingkungannya. 
Tabel 1 menunjukkan bahwa 33,3\% ibu dari anak yang dititipkan ke TPA berpendidikan menengah, dan $66,7 \%$ berpendidikan tinggi. Sedangkan tingkat pendidikan ayah menunjukkan $6 \%$ memiliki tingkat pendidikan dasar, 33,3\% berpendidikan menengah, dan $60,7 \%$ tingkat pendidikan tinggi.

Hasil pengisian kuesioner pengasuh anak di delapan TPA di Banjarmasin menunjukkan bahwa pengasuh dengan tingkat pendidikan dasar $6,67 \%$, tingkat pendidikan menengah $83,3 \%$, dan pendidikan tinggi 19\% (Tabel 2). Selain itu, semua pengasuh TPA pernah mengikuti pelatihan dan seminar mengenai anak baik oleh dinas pendidikan, dinas sosial ataupun pihak-pihak terkait lainnya, sehingga diharapkan tingkat pendidikan dan pengetahuan pengasuh TPA di Banjarmasin tentang pengasuhan anak sudah cukup memadai.

\section{Pembahasan}

Perkembangan bicara dan bahasa anak tersebut dinilai dengan instrumen Early Languange Milestone Scale-2 (ELMs-2), yang difokuskan pada bidang ekspresi, re-

Tabel 1. Karakteristik orangtua anak di 8 TPA di Banjarmasin

\begin{tabular}{lc}
\hline Karakteristik Orang Tua & Persentase \\
\hline Tingkat pendidikan ibu & \\
Pendidikan dasar & - \\
Pendidikan menengah & 33,3 \\
Pendidikan tinggi & 66,67 \\
\hline Tingkat pendidikan ayah & \\
Pendidikan dasar & 6 \\
Pendidikan menengah & 33,3 \\
Pendidikan tinggi & 60,7 \\
\hline Pendapatan /bulan (rupiah) & \\
$<750.000$ & 6,67 \\
$<1.500 .000$ & 6,67 \\
$<2.000 .000$ & 20 \\
$>2.000 .000$ & 66,67 \\
\hline
\end{tabular}

$\mathrm{n}=33$

Tabel 2. Tingkat pendidikan pengasuh anak di 8 TPA di Banjarmasin

\begin{tabular}{lc}
\hline Tingkat pendidikan pengasuh & Persentase \\
\hline Pendidikan dasar & 6,67 \\
Pendidikan menengah & 83,33 \\
Pendidikan tinggi & 10 \\
\hline
\end{tabular}

$\mathrm{n}=30$ septif dan visual anak, terutama melalui laporan orang tua dan kegiatan tes langsung pada anak. Hasil tes ditunjukkan dengan pernyataan "lulus" atau "gagal". Tes dilakukan dengan waktu pengerjaan 1-4 menit, dikerjakan oleh dokter, psikolog, perawat, audiolog, speech pathologist, dan guru. ${ }^{2,7-10}$ Ditemukan beberapa anak yang menunjukkan perkembangan bicara dan bahasa yang lebih baik dari pada anak seusianya, yaitu $33,3 \%$, dengan kata lain kemampuan berkomunikasi mereka di atas rata-rata anak seusianya.

Hal tersebut sesuai dengan penelitian NICHD yang juga menemukan bahwa anak berumur 6 bulan ke atas yang memiliki pengalaman di pusat perawatan anak lebih lama, menunjukkan suatu perkembangan kognitif dan bahasa yang lebih baik daripada anak yang hanya diasuh di rumah. Diperkirakan anak di pusat perawatan lebih banyak menerima pola bahasa yang berbeda-beda, lingkungan yang lebih banyak mempunyai stimulasi bahasa dan lebih banyak kesempatan untuk bertemu dengan teman sebayanya sehingga memungkinkan anak agar lebih banyak bicara untuk mengungkapkan keinginannya. ${ }^{6,11,12}$ Anak-anak tersebut mendapatkan pengalaman dan rangsangan perkembangan dari lingkungan TPA karena adanya interaksi yang intensif dan kuat setiap harinya.

Tingkat pendidikan merupakan salah satu faktor dari kualitas pengasuhan anak. Penelitian oleh NICHD menyimpulkan bahwa anak yang mendapatkan pengalaman perawatan dengan kualitas yang tinggi secara konsisten menunjukkan fungsi kognitif dan perkembangan bahasa yang lebih baik sepanjang tiga tahun pertama kehidupannya. Penelitian Pancsofar dan Vemon-Feagans ${ }^{13}$ menemukan bahwa tingkat pendidikan orangtua mempunyai pengaruh yang bermakna pada kemampuan bicara dan bahasa anaknya, sebab memberi dampak pada pola bahasa dalam keluarga. Zadeh dan Bolter ${ }^{14}$ menyatakan tingkat pendidikan orangtua dan pola pikir orangtua yang tradisional yang bersifat negatif seperti seorang anak harus mengikuti perintah orangtuanya tanpa boleh bertanya atau mengharapkan kepatuhan sepenuh dari anaknya, memiliki hubungan yang tinggi. Mereka menyimpulkan bahwa orangtua dengan tingkat pendidikan yang rendah lebih cenderung untuk memiliki pola pikir tradisonal, sehingga bersikap otoriter kepada anaknya yang nantinya akan menghambat perkembangan bahasa dan bicara anak, dan selanjutnya mempengaruhi prestasi anak tersebut. Sementara itu, untuk tingkat pendapatan 
orang tua diketahui bahwa orang tua yang dibagi menurut pendapatan kurang dari Rp.750.000,00 $(6,67 \%)$, orang tua dengan pendapatan kurang dari Rp. 1.500.000,00 (6,67\%), pendapatan kurang dari Rp. 2.000.000,00 (20\%), dan pendapatan lebih dari Rp.2.000.000,00 (66,67\%), dapat disimpulkan bahwa sebagian besar anak yang dititipkan di TPA berasal dari keluarga dengan tingkat ekonomi tinggi, karena rata-rata penghasilan orangtua berada di atas batas garis kemiskinan kota Banjarmasin, yaitu Rp 216.538,00/ kapita/bulan. ${ }^{15}$

Noel $\mathrm{dkk}^{16}$ (2008) menyatakan keadaan ekonomi keluarga yang tidak menguntungkan dengan pendapatan kecil akan meningkatkan tekanan dalam keluarga, menciptakan stress secara psikologis dan mempengaruhi kualitas interaksi antara orangtua dan anaknya, sehingga akan mempengaruhi perkembangan anak tersebut. Selain itu, orangtua berpendapatan kecil tidak dapat membayar pengasuhan yang lebih baik, ${ }^{17}$ sedangkan keluarga yang mempunyai pendapatan lebih besar lebih cenderung untuk menggunakan fasilitas pengasuhan dengan kualitas yang tinggi. ${ }^{18}$

Beberapa data karakteristik, dapat dimasukkan sebagai faktor yang mempengaruhi perkembangan bicara dan bahasa anak. Namun kami tidak dapat membuktikan faktor mana yang paling berpengaruh pada perkembangan bicara dan bahasa anak, hanya dapat menguraikan beberapa data karakteristik yang diduga sebagai faktor pendukung perkembangan bicara dan bahasa anak.Penelitian Pancsofar dan Vemon-Feagans ${ }^{13}$ menyatakan semua keluarga dengan tingkat pendidikan dan ekonomi yang menguntungkan akan mempunyai anak dengan risiko lebih rendah untuk mengalami keterlambatan perkembangan bicara dan bahasa. Penelitian tersebut menunjukkan bahwa semua anak di TPA mengalami perkembangan bicara dan bahasa yang baik dengan tingkat pendidikan pengasuh (orang tua dan pengasuh TPA) yang tinggi serta berasal dari keluarga dengan keadaan ekonomi baik pula.

Penelitian kami memiliki beberapa keterbatasan, yaitu tidak dapat membahas dan menilai hubungan semua faktor yang mempengaruhi perkembangan bicara dan bahasa anak. Faktor yang diteliti hanya tingkat pendidikan orangtua dan pengasuh di TPA serta tingkat ekonomi keluarga. Selain itu peneliti tidak melakukan wawancara secara langsung kepada orangtua seperti yang dilakukan kepada pengasuh. Sebagai kesimpulan perkembangan bicara dan bahasa anak usia 0-3 tahun di delapan TPA Banjarmasin adalah normal, sesuai dengan tahapan perkembangan pada usia masing-masing anak.

\section{Daftar pustaka}

1. Soetjiningsih. Gangguan bicara dan bahasa pada anak. Tumbuh kembang anak. Jakarta: EGC, 1995.h.237-47.

2. Permono B, Kaspan MF, Soegijanto S. Kapita selekta Ilmu Kesehatan Anak VI Surabaya: FK Unair-RSU Dr. Soetomo, 2006.

3. American Academy of Pediatrics. Identifying infants and young children with developmental disorders in medical home: an algorithm for developmental survaillence and screening. Pediatric 2006; 118: 405-18.

4. US Preventive Services Task Force. Screening for speech and language delay in preschool children: recommendation statemen. Pediatrics 2006; 117: 497-501.

5. Behrman, Kliegman, Arvin. Ilmu kesehatan anak nelson vol.1. Jakarta: EGC, 2000.

6. National Institute Of Child Health And Human Development (NICHD). Study of early child care and youth development (seccyd) 2006; Didapat dari: URLhttp:// www.nichd.nih.gov, diakses tanggal 1 Mei 2008).

7. Walker D, Gugenheim S, Downs MP, Northern JL. Early language milestone scale and languge screening of young children. Pediatric 1989; 83: 284-8.

8. Law J, Boyle J, Harris F, Harkness A. Screening for speech and language delay: a systematic review of the literature. Health Technology Assessment Review 1998; 2:52-4.

9. Lima MCMP, Barbarini GC, Gagliardo HGRG, Arnais MA, Gonçalves VMG. Observation of language, visual and hearing function development. Rev Saúde Pública 2004; 38:874-8.

10. Singhi PMP. Screening young children for delayed development. Department of pediatrics. Indian Pediatrics 1999; 36: 569-77.

11. Albar H, Palada P. Taman penitipan anak. Kesehatan anak Fakultas Kedokteran Universitas Hasanuddin RSU Ujung Pandang, Ujung Pandang. CDK 1992; 75.

12. National Institute Of Child Health And Human Development early child care research network. The relationship of children care to cognitive and language development. Child development 2000; 71: 960-80.

13. Pancsofar N, Vemon-Feagans L. Mother and father language input to young children: contributions to later language development. J Appl Dev Psy 2006;27:57187 
14. Zadeh ZY, Bolter-Im N. Parenting beliefs and academic achievement: the mediation role of language. Canadian Pshycological Association Ottawa, Canada 2007.

15. BPS Provinsi Kalimantan Selatan. Berita resmi statistik provinsi Kalimantan Selatan: tingkat kemiskinan di Kalimantan Selatan Maret 2008 - Maret 2009. No.21/07/63/ Th.XII. 1 Juli 2009.

16. Noel M, Peterson C, Jesso B. The relationship of parenting stress and child temperament to language develop- ment among economically disadvantaged preschoolers. J. Child Lang. 2008; 35: 823-43.

17. Japel C, Tremblay RE, Côté S. Quality counts: assessing the quality o daycare services based on the quebec longitudinal studyof child development. Irpp Choices 2005;11:165-8.

18. Shonkoff JP, Phillips DA. From neurons to neighborhoods: the science of early childhood development. Washington DC. National Academy Press 2000. 